Article

\title{
Characteristics and Satisfaction Analysis of Eco-Tour Ships at Ecotourism Sites: Focusing on the Cases of the Nakdong River Estuary, Suncheon Bay Wetland, and Goesan Lake and Sanmagi-Yetgil in Korea
}

\author{
Byung-Chul An ${ }^{1}$ a and Eun-Yeong Park ${ }^{2, *} * \mathbb{D}$ \\ 1 Department of Forest-Landscape Architecture \& Institute for Environmental Science, Wonkwang University, \\ Iksan 54538, Korea; askpp1048@wku.ac.kr \\ 2 Department of Environment \& Landscape Architecture, Joongbu University, Geumsan 32713, Korea \\ * Correspondence: eypark@joongbu.ac.kr; Tel.: +82-41-750-6294
}

Received: 27 August 2020; Accepted: 14 November 2020; Published: 17 November 2020

check for updates

\begin{abstract}
This study investigated eco-tour ships at Nakdong estuary, Suncheon wetland, and Goesan and Sanmagi-yetgil, 3 of the 26 ecotourism sites in Korea, by analyzing the characteristics and level of ecotourist satisfaction. The field investigation focused on eco-tour ship image, facilities, landscape observed from eco-tour ship, course, and operations. The results of the satisfaction analysis can be summarized as follows. First, there was no significant difference in satisfaction of eco-tour ship image between Nakdong estuary and Sanmagi-yetgil $(p>0.01)$, while Suncheon wetland showed a significant difference $(p<0.01)$. It is assumed that the fact that the ship was built using timber which better suits the natural environment and coastal ecosystem had a positive impact on the visual image. No significant difference in satisfaction with facilities on eco-tour ships was found between Nakdong estuary and Suncheon wetland, while Sanmagi-yetgil showed a significant difference. Second, satisfaction of the landscape observed from the eco-tour ships showed significant differences in the mean scores of landscape evaluation the three target sites: Sanmagi-yetgil (8.40), Suncheon wetland (7.20), and Nakdong estuary (4.67). These values are based on the qualitative evaluation of the landscape as seen from the eco-tour ship. It is presumed to have been influenced by the diversity of the landscape and the width of the river. The eco-tour ship course satisfaction also showed significant differences in the mean scores: Sanmagi-yetgil (7.37), Suncheon wetland (6.57), and Nakdong estuary (5.00). The landscape and tour course evaluations of the respondents seem to be correlated. In particular, the variety of courses available to visitors in Sanmagi-yetgil was relatively high compared to Nakdong estuary and Suncheon wetland. Third, satisfaction analysis for eco-tour ship operations found that Suncheon wetland and Sanmagi-yetgil did not differ significantly in terms of satisfaction $(p=0.634)$, but Nakdong estuary showed a significant difference. The relatively low satisfaction with the eco-tour ship operation at Nakdong estuary is due to the low scores for eco-tour ship commentary, reservation system, and with the facilities, while it is shown that the operation time as well as the landscape observed from the eco-tour ship and the tour course had a combined influence on satisfaction. In the comparative analysis of the impact of eco-tour ships on ecotourism, Nakdong estuary showed a significant difference. This finding indicates a greater influence of eco-tour ships on ecotourism in Suncheon wetland, Sanmagi-yetgil, and Nakdong estuary. Enhanced ecotourism satisfaction improves the probability of return visits. Thus, there is a need to incorporate the characteristics of ecological resources with well thought out operation and increased functional suitability of eco-tour ships to improve ecotourism satisfaction. The eco-ships in the three places in this paper have elements promoting and enhancing their potential. Our findings showed the satisfaction level of the users with the theme of ecotourism.
\end{abstract}


Keywords: eco-tour ship image; facility satisfaction; landscape; eco-tour ship course; operation; impact on ecotourism

\section{Introduction}

Ecotourism is a form of sustainable tourism based on the natural environment, with a focus on experiencing and learning about nature. Ecotourism aims to minimize the impact on the environment and to achieve nonconsumptive and ethical management of natural resources [1,2]. Thus, the importance of three factors is emphasized: relatively unharmed natural regions, increased awareness of environmental issues by the provision of opportunities for environmental education, and consideration of local communities [3]. Ecotourism has grown steadily despite various issues, such as the negative impacts of the tourism industry on the ecosystem due to active nature conservation activities [4], economic incentives considering social costs [5], socioeconomic impacts on ecotourism [6], conflict between the enjoyment of recreation and nature conservation [7], the adaptation of tourism to the issue of climate change and the need for emissions reduction [8]. In recent years, ecotourism has been recognized as creating environmentally friendly tours to preserve biodiversity and protect endangered species in this era of climate change [9]. Ecotourism directly/indirectly provides economic benefits, including regional development, increases in income, improvement in added value and the creation of new job opportunities, according to a previous analysis [10].

The elements that constitute ecotourism are the inherent resources of the target site, nature-related programs, and the operating body. Natural resources include organic and inorganic entities that have adapted to the given regional topography and climate over a long time; these resources are the main element of ecotourism. Through exploring such resources, participants in ecotourism learn to recognize the value of nature. This is what makes exploration programs uniquely important. Such programs are continuously evolving and range from natural learning and experience using learning tools to a means of exploring and monitoring endangered species and rare animals and plants. Regarding the function of ecotourism, diverse programs have a complementary relationship. When the focus is on landscape values of the ecosystem rather than on ecological conservation, ecotourism sites with low visual attractions in the form of ecological resources tend to rely more on educational programs [11]. It should be taken into account that the significance of the landscape value increases within the ecosystem perceived by the ecotourists. To increase ecotourists' satisfaction with ecological factors, in addition to the conservation of the ecosystem, effective programs that enhance and present the diversity of the beautiful landscape should be prepared. Furthermore, the natural attributes of ecotourism resources and various environmental education and experience programs influence ecotourism participants during ecotourism activities. This may be interpreted as the basis on which ecotourists can reinforce the ecofriendly attitude they had already formed before visiting the site in a more sophisticated manner [12]. Unique regional resources and exploration programs are essential for vitalizing ecotourism, as they convey the significance and value of ecotourism to ecotourists. Stakeholders, such as operating bodies and their collaborators, have shown much interest in promoting the efficiency of exploration programs regarding the value of resources.

As of 2020, there are 26 ecotourism sites in Korea as designated by the Ministry of Environment. According to the topographical and geographical characteristics of a given site, a site may be classified as a mountain, lake, river, coast, or village. Each site has unique natural resources and exploration programs [13]. There are programs that use ships to explore water ecosystems to increase the interest of ecotourists [14,15]. The learning in such programs involves the observation of natural ecosystems, such as rivers, streams, and marshes, as well as the cultural resources on the ship. The use of ships at ecotourism sites provides visitors not only with the chance to explore ecological resources but also transportation to destinations and amenities on board. In addition, such ecotourism programs provide opportunities to experience interesting water-themed projects $[15,16]$. For ecotourism participants, 
the ship floating on water in itself is a unique experience, while it also has various other functions. The ship's original purpose is to serve as a platform for exploring and learning about natural ecological resources. Moreover, a panoramic landscape accompanied by commentary on the ship can help ecotourists experience waterway cultural resources. In addition to offering transportation, the ship provides healing and leisure facilities. The ships used in ecotourism are mostly referred to as "eco-tour ships" to reflect their key purpose of exploring ecological resources.

Ecotourism participants can thus realize the goal of ecological exploration together with the added value of experience on an eco-tour ship, which may be viewed as the most active water-friendly facility. However, a considerable level of criticism has been levied against the function and role of eco-tour ships used at ecotourism sites in Korea. Remodeled ships originally constructed for a different purpose or ships primarily built for cruising purposes that are borrowed and used as eco-tour ships are often considered to indicate poor-quality ecotourism and are evaluated as undeserving of the term "eco-tour." Analyzing satisfaction in the field of tourism is not a new concept. Considering that the only way to determine the function and role of eco-tour ships at ecotourism sites in Korea is to collect opinions from ecotourists after an experience and to rely on subjective conclusions made by experts, the satisfaction analysis method seems appropriate as a framework to explain the process of extracting visitors' destination choice attributes, motivations, and satisfaction [14,17].

Among the 26 ecotourism sites in Korea, the following three sites utilize waterway programs and eco-tour ships: the Nakdong River estuary, Suncheon Bay wetland, and Goesan Lake and Sanmagi-yetgil.

In this study, the same subjects were engaged in ecotour ship experiences at all three target sites in an identical manner, and the results were analyzed in relation to the following three questions:

1. What are the individual characteristics of the eco-tour ships at the three target sites?

2. What causes the different levels of satisfaction with each factor of the eco-tour ship?

3. Does the use of eco-tour ships impact ecotourism?

The answers to these questions can be found through field investigations of eco-tour ships and comparisons and analyses of satisfaction with the use of eco-tour ships. The findings will contribute to improving the facilities and programs related to eco-tour ships. Furthermore, ecotourism motivation can be deducted, and the quality of ecotourism can be enhanced to promote sustainable ecotourism.

\section{Theoretical Background}

\subsection{Destination Choice Attributes and Motivation}

To date, studies on ecotourism have mainly focused on institutions and policies [18], the promotion of ecotourism in specific regions [19,20], and tourism attitudes, motivation, and satisfaction [21-23]. Among the various factors, the type of exploration program has been reported to be a critical motivation of destination choice.

The choice attributes for a given destination indicate the importance of the attributes that are considered when choosing a destination and the satisfaction perceived after experiencing the choice. The choice attributes influence the subjective choice and the behavior of ecotourists regarding the destination. Moreover, the decision-making process is based on the comparison of choice attributes that reflect personal opinions [24]. The subjective perception and emotions towards a particular place influence the intention to visit the place and ultimately affect the active use of that place. Thus, the analysis of choice attributes is crucial [25]. It is important to identify and improve the choice attributes of a specific factor by investigating whether the factor influences the perception and efficient use of a given place [26]. A study on the congruity between the choice motivation, expectation, and experience of ecotourism sites and the influence on satisfaction [27] reported that unlike social motivation, extraordinary motivation has no effect on overall satisfaction. The stronger the extraordinary motivation, the more the perceived experience at ecotourism sites is 
below expectations. Thus, there is the potential to obtain more positive results through marketing experience or ecological education programs that target groups with shared social motivations, such as families, coworkers, or social organizations.

\subsection{Ecotourism Satisfaction}

A study on the influence of ecotourists' environmental attitudes on their satisfaction [11] found the destination as a product itself and as a region or place that attracts ecotourists [28] and destination attractiveness to have substantial influence on the intention to visit or revisit and on the perception of the destination [29]. Destination attractiveness comprises the value of the benefits that ecotourists pursue and the belief that such benefits will be provided by the destination [30]. It may also be defined as a relationship between the potential use of factors creating attractiveness and the perceived effects after experiencing these factors. The way the benefits of attractiveness are delivered to the participants is also critical [31]. To meet the changing demands of ecotourists, destinations need to reorganize or redevelop the attractiveness attributes [32,33]. A study on the correlation between satisfaction and quality commentary in ecotourism [34] found that commentary systems have an effect on ecotourism satisfaction. The success of the commentary program was reported to depend on the quality of the commentary. It is thus necessary to enhance the quality of commentary to maximize the positive effects, such as promoting environmental conservation. The study pointed out the importance of enhanced quality with respect to expertise, intrigue, curiosity satisfaction, and appropriate language use in delivering the commentary information of an ecotourism program. In another study on the moderating effects of public interest contribution on the relationship between satisfaction and the perceived value of ecotourism [35], values related to emotion, function, and perception were shown to have a moderating effect. In addition, the perceived value of ecotourism necessitated the development of various programs in line with the diverse needs of ecotourists, for whom emotional values and curiosity played a more significant role than the functional values.

The development of ecotourism programs that can stimulate emotions and curiosity is thus considered an essential factor in promoting ecotourism. The perception of a given place includes the satisfaction obtained after the experience of having visited and enjoyed the place and the satisfaction that comes from personal awareness and experience in daily life [36]. An influential level of awareness and satisfaction is likely to be created through exploration programs that combine spatial and environmental factors, independent of the rationality of enjoying the target site itself and appreciating the various spatial features.

\subsection{Eco-tour Ships in Korea}

The 26 ecotourism sites in Korea can be divided into a number of types according to the location and topographical characteristics of the target site and its use by ecotourists. According to location, the site is either urban or nonurban; according to topography, the site type is mountain, lake, river, coast, or village; and as per use by ecotourists, the type has either an exploring or a learning function. In some cases, the ecotourism site has already been designated as a Ramsar wetland, a wetland conservation area, or an ecosystem conservation area [13]. Each ecotourism site differs in the main resources present, while depending on the operating body, the exploration programs may also vary.

The use of eco-tour ships as part of the ecotourism program can be seen in lakes, streams, and coasts, with the exception of mountain types. Among these sites, an eco-tour ship program based on regular sailing and commentary can be found in the Nakdong River estuary, Suncheon Bay wetland, and Sanmagi-yetgil, which are the target sites in this study. Other sites with such programs include Youngsan-8-gyeong cruising at the Village of Excellence in Youngsan Island, pole boating at Upo Marsh, and canoeing at Seonheul-ri on Jeju Island. However, these cases involve leisure ships rather than regular eco-tour ships and are thus excluded from this study. 


\subsection{Ecotourism and Carbon-Neutral Future}

Climate change has created threats, such as global warming and abnormal climate events. This has led to the need for a new paradigm for the existing tourism industry, which utilizes specific resources in a specific region. The existing tourism industry has been energy intensive and sensitive to climate change. Tourist activities and the development of tourist spots have destroyed the ecosystem. The transportation of tourists and tourist facilities emits high amounts of greenhouse gases [37]. Therefore, we need to rethink the concept of tourism that has depended on the destruction and consumption of nature and consider an ecological approach instead of an economic approach to tourism [9].

To evaluate the impact of the tourism industry on the environment, we chose two studies among many: a study that qualified the environmental burden per tourist and established evidence to minimize the environmental impacts of tourism [38] and a study that evaluated the characteristics of regions and industries throughout the entire process to estimate the carbon footprint from foreign tourists in Iceland [39]. In addition, research was conducted for the development and evaluation of low-carbon ecotourism indicators to activate ecotourism [40]. Among the positive effects of ecotourism, we need to focus on carbon-neutral benefits through energy/resource savings and the reduction of carbon dioxide emissions, which is a major cause of climate change, such as global warming.

\section{Materials and Methods}

\subsection{Study Scope and Area}

There are a total of 26 sites for ecotourism recognized by the Korean government. Among these sites, there are three places where the ecology can be explored and experienced using ships. These three sites are the scope of our research. The spatial scope of this study includes the Nakdong River estuary, Suncheon Bay wetland, Goesan Lake and Sanmagi-yetgil, where eco-tour ships are currently in operation as part of the waterway utilization program (Figure 1).

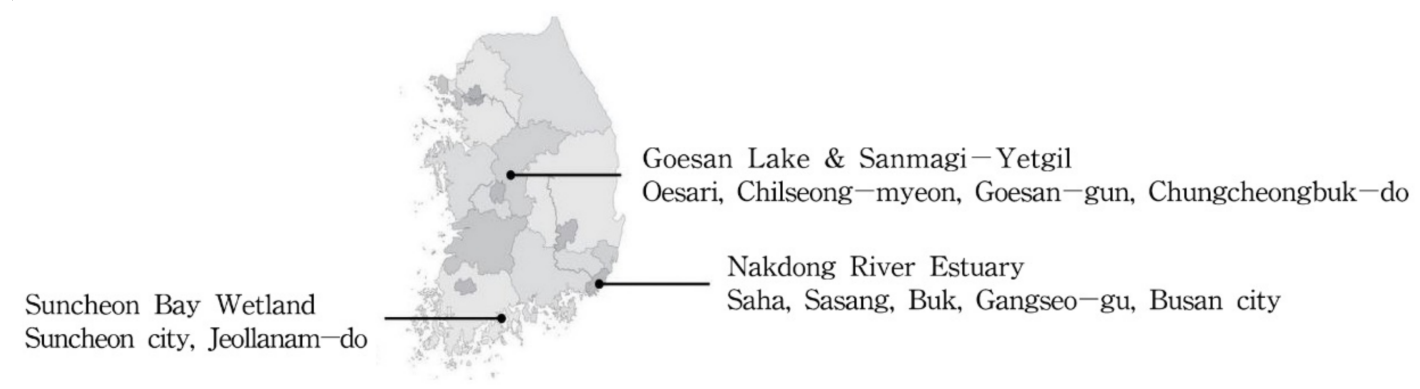

Figure 1. Study area.

The Nakdong River estuary has an area of approximately $330 \mathrm{~km}^{2}$ from Mulgeum to Dadaepo. The land area accounts for approximately $170 \mathrm{~km}^{2}$, including the agricultural lands of Hajungdo and Gangseo-gu and the urban areas, while the sea area is approximately $160 \mathrm{~km}^{2}$, including tidal flats, offshore bars (Doyodeung, Sinjado, Jinudo, Daemadeung, Jangjado, Maenggeummeori, etc.), Eulsukdo Island $\left(3.1 \mathrm{~km}^{2}\right)$ and Gadeokdo Island [41]. The Nakdong River estuary was designated an ecotourism site in 2013, and the administrative districts are Busan Metropolitan City, Sasang-gu, Seo-gu, Saha-gu, Gangseo-gu, and Gimhae city. The main ecological hub is the Nakdong River main stream, and Eulsukdo, Dunchido, Samrak, Maekdo, Daejeo, and Hwamyeong ecological parks along the Nakdong River. The offshore bars border the open sea, providing habitat to an estimated 223 species of 100,000 migratory birds and supporting vegetation and wild animals that are commonly found in a brackish water zone. However, ecotourism ships are not currently in operation to explore the coastal land of the sea. The eco-tour ship currently covers a round trip of $48 \mathrm{~km}$, from Eulsukdo Marina to Mulgeum Marina in Yangsan city, passing through the Hwamyeong ecological park in Buk-gu. 
The width of the stream is approximately 0.5 to $1.2 \mathrm{~km}$. From the ship, the Eomgung Marsh at Nakdong River main stream, Maekdo Marsh, various birds inhabiting the areas around Samrak ecological park, and waterside landscape can be seen faintly. A single eco-tour ship with a passenger capacity of 33 is in operation. Nine specialized culture and tourism commentators offer commentary on the ship. The commentary focuses on describing the habitats of migratory birds in the Nakdong River estuary, along with the history and culture of the regions, including Gupo Station, Gaya historic site, and Eden park [42,43].

Suncheon Bay wetland stretches over an area of approximately $28 \mathrm{~km}^{2}$ along Suncheon city in Jeollanam-do. Similar to the Nakdong River estuary, the Suncheon Bay wetland was designated an ecotourism site in 2013 and is also a Ramsar site. It provides habitat to 36 families, 92 genera, and 116 species of plants and numerous birds, including the hooded crane, which was designated as natural monument No. 228, and Saunders's gull, dunlin, black-faced spoonbill, and oriental stork. A single dense community of reeds is also of particular interest. The reed community spread over an area of approximately $5.4 \mathrm{~km}^{2}$ in the vicinity of the tidal flat close to the shore is the largest reed community in the nation and serves as a key resource of ecotourism [13]. The eco-tour ship at Suncheon Bay wetland currently covers a regular round trip of approximately $6 \mathrm{~km}$ in approximately $40 \mathrm{~min}$. Through the waterway formed across the tidal flats of Suncheon Bay wetland, one can explore the reed community up close and view the rich variety of birds, including hooded cranes, grey herons, sandpipers, and ducks. The landscape of the Gaetgol ecological park in Suncheon Bay wetland as seen from the eco-tour ship is the main attraction of the ecotourism program. Three eco-tour ships are currently in operation. Ecopia vessel 1 has a passenger capacity of 34, while Ecopia vessels 2 and 3 can accommodate 32 people each. The ships operate from an hour after sunrise until sunset and are principally run on a reservation basis. The purpose of the tour is to explore the brackish water zone where rivers and seas meet. The width of the stream is approximately 80 to $200 \mathrm{~m}$, so observations on the ship are relatively clear. The coastal area is approximately $2.3 \mathrm{~km}$ wide, but it includes mudflats, making it easy to observe the ecosystem.

Goesan Lake and Sanmagi-yetgil are located in Saeun-ri, Chilseong-myeon, Goesan-gun, and Chungcheongbuk-do. The region is centered around the yetgil (old road) trail of approximately $3.9 \mathrm{~km}$ and the Dalcheon Stream that branches off the Namhan River, and was designated an ecotourism site in 2014. The $3.9 \mathrm{~km}$ yetgil trail connects Saorang village to Sanmaki village. The historical, cultural, and ecological linking of resources in the vicinity enhances ecotourists' satisfaction with the region. The dominant species surrounding the yetgil are oak and pine trees. The natural habitat of white forsythia, designated natural monuments No. 220 and No. 221, can also be explored. Furthermore, the 26 storytelling points, created artificially along Sanmagi-yetgil, arouse ecotourists' interest in cultural resources. Exploration of the Goesan Lake waterway, together with the walk along the yetgil trail, is the key program of ecotourism in this region. Originally, the program course ran from Chadolbawi Marina to Sanmagi Marina. Later, with the increase in the number of tourists, it was expanded to allow the ecotourists to explore the entire stretch of Dalcheon Stream, including Sanmagi-yetgil. The width of the stream is approximately 85 to $220 \mathrm{~m}$, and the waterfront ecosystem can be observed relatively clearly from aboard the ship. The ecotourism commentary on the ship, which weaves together the natural landscape and humanistic factors, leads ecotourists to fully enjoy the ecotourism experience. A total of six eco-tour ships are in operation: four at Bihakbong village and two at Gulbawi farm. The required time varies according to the course, ranging from $40 \mathrm{~min}$ to $1 \mathrm{~h}$, on average, while the operation is flexible depending on the eco-tour ship managing agency.

\subsection{Research Method}

The purpose of this study is to comparatively analyze the problems in using eco-tour ships at the three target sites and the level of ecotourist satisfaction based on the data obtained from a survey on the rediscovered values of eco-tour ships and functional enhancement with respect to ecotourism. The aim is thus to provide basic data for the use of eco-tour ships and the promotion of ecotourism. 
The research method can be broadly divided into a literature review, field investigation, and statistical analysis. The procedure is as follows: analysis of the literature and a field investigation regarding the ecotourism resources at the three target sites; construction of a survey questionnaire; production of a statistical program for the survey and individual survey items regarding the ecotourists' use of eco-tour ships; and result derivation. The survey items regarding eco-tour ships were created based on the results of the literature review and field investigation conducted in parallel for the three target sites. For the questionnaire items, factors related to the unique functions of eco-tour ships introduced as part of ecotourism and the eco-tour ship programs were listed. Then, findings from previous studies and expert opinions were integrated, and six items were selected in total. The survey focused on the functional suitability of the eco-tour ship, the rationality of the eco-tour ship course, eco-tour ship operations, and the impact of eco-tour ships on ecotourism with respect to the onboard exploration of ecotourists participating in ecotourism (Table 1).

Table 1. Items of question investigation.

\begin{tabular}{|c|c|c|c|}
\hline & Article & & Article \\
\hline \multirow{2}{*}{ Ship facilities } & $\begin{array}{l}\text { 1. Image as an ecological } \\
\text { exploration ship }\end{array}$ & \multirow{2}{*}{ Quality of commentator } & \multirow{2}{*}{$\begin{array}{l}\text { 5. Operational method and } \\
\text { quality of commentator }\end{array}$} \\
\hline & $\begin{array}{l}\text { 2. Facilities on the ecological } \\
\text { exploration ship }\end{array}$ & & \\
\hline \multirow{2}{*}{ Rationality of the course } & $\begin{array}{l}\text { 3. Ecological landscape observed } \\
\text { from the ship }\end{array}$ & \multirow{2}{*}{ Influence } & \multirow{2}{*}{$\begin{array}{l}\text { 6. Effect of ecotourism } \\
\text { on the community }\end{array}$} \\
\hline & 4. Tour course and time required & & \\
\hline
\end{tabular}

For the functional suitability of the eco-tour ship, the eco-tour ship image and the facilities on the eco-tour ships were investigated with respect to the exploration of ecological resources, which is the key aspect of ecotourism. For rationality of the course, the suitability of the ecological and landscape resources of the target site that can be observed from the eco-tour ship and the appropriateness of the course and time provided to the ecotourists were investigated. The landscape resources refer to the landscape characteristics of the area surrounding the waterway and include the aesthetic factors of the physical entities and the pleasant feelings experienced by the ecotourists on the ship. This may also be regarded as the main factor in maintaining a balance between the existing entities, landmark presentation, and realized sense of place created by the spatial structure [44]. Ecological resources are the resources centered on management and conservation and may be viewed as the identity of ecotourism. For eco-tour ship operations, the eco-tour ship schedule, reservation system, efficient service, and satisfaction with the commentary on the ship were investigated. Finally, the impact of eco-tour ships on ecotourism was investigated. A 10-point Likert scale was used to measure satisfaction (1: not satisfied at all; 10 : very satisfied).

The study participants were 30 undergraduate students, each of whom experienced all three target sites in a similar way. The survey was conducted from 1 May to 10 September 2018. Data from the 90 questionnaire responses from the survey of each target site were statistically analyzed. In addition, interviews were conducted with ordinary citizens on board the ship at each target site for reference when analyzing the survey results.

The survey responses were analyzed using two statistical programs: Microsoft Office Excel 2013 and SPSS 24.0, Windows. For the general characteristics of samples, frequency analysis of the measured items, and correlation with the level of satisfaction, the Kruskal-Wallis test at the $1 \%$ significance level $(p=0.01)$ was performed. In addition, the Mann-Whitney test was performed to confirm the significance of the differences in the comparative analysis. The Kruskal-Wallis test is a method of testing the differences between multiple samples in batches. This is a nonparametric analysis method. The Mann-Whitney test is also a method for testing the equality between two groups.

It is noteworthy that the methodology employed in this study is characterized by the fact that the same 30 survey respondents visited the three target sites and responded to the same set of 
questionnaires. As the study relied on comparative analysis, this is presumed to have had a positive influence on the reliability of the statistical analysis.

\section{Results}

\subsection{Field Investigation and Eco-Tour Ship Analysis}

The field investigation of eco-tour ships at the three ecotourism target sites focused on the eco-tour ship image, facilities on the eco-tour ship, landscape observed from the eco-tour ship, eco-tour ship course (distance and time), and eco-tour ship operations. The findings of the investigation were explained to the respondents. The data regarding ship specifications, tour course, and operations were prepared in advance and provided to the respondents (Table 2).

Table 2. Site comparison.

\begin{tabular}{|c|c|c|c|}
\hline & Nakdong River Estuary & Suncheon Bay Wetland & $\begin{array}{c}\text { Goesan Lake and } \\
\text { Sanmagi-Yetgil }\end{array}$ \\
\hline Administrative districts & $\begin{array}{l}\text { Saha, Sasang, Buk, } \\
\text { Gangseo-gu, Busan }\end{array}$ & $\begin{array}{l}\text { Suncheon city, } \\
\text { Jeollanam-do }\end{array}$ & $\begin{array}{c}\text { Oesari, Chilseong-myeon, } \\
\text { Goesan-gun, } \\
\text { Chungcheongbuk-do }\end{array}$ \\
\hline Round trip distance & $\begin{array}{l}30 \mathrm{~km} \\
\text { * principally used for } \\
\text { round trip }\end{array}$ & $\begin{array}{l}6 \mathrm{~km} \\
\text { * only round trip }\end{array}$ & $\begin{array}{l}10 \mathrm{~km} \text { (one way, } 5 \mathrm{~km} \text { ) } \\
{ }^{*} \text { principally used for } \\
\text { one-way trip }\end{array}$ \\
\hline Time required & 90 min (round trip) & 35 min (round trip) & $\begin{array}{c}40 \mathrm{~min} \text { (one way) } \\
60 \mathrm{~min} \text { (round trip) }\end{array}$ \\
\hline Eco-tour ship & & & \\
\hline Specification & 33-seater boat, 10 knots & 34 -seater boat, 10 knots & 30-seater boat, 10 knots \\
\hline \multirow[t]{2}{*}{ Course } & West Nacdong iner & & \\
\hline & $\begin{array}{l}\text { Eulsukdo } \\
\text { ferry-Hwamyeong Eco } \\
\text { park-Mulgeum ferry }\end{array}$ & $\begin{array}{l}\text { Daedae ferry-“S" type } \\
\text { coastal wetland } \\
\text { waterway-Daedae ferry }\end{array}$ & $\begin{array}{l}\text { Chadolbegi ferry-Galon } \\
\text { naru-Saebengi ferry }\end{array}$ \\
\hline
\end{tabular}

*: The method of use of a ship, which means round trip or one way use.

As indicated in Table 3, the landscapes viewed from the eco-tour ship at the three sites are divided into far away, medium distance, and close distance. The physical distance at which a visitor can experience each site's waterside landscape is $400 \mathrm{~m}, 150 \mathrm{~m}$, and $120 \mathrm{~m}$, on average, away from the eco-tour ship (central line of the river), respectively, for each site. Site 1 (the Nakdong River estuary), which is a national river, is considerably wide and provides good comfort, but it is not easy to recognize the landscape located far away. In addition, there are many artificial structures incorporated in its landscape, such as urban apartment buildings. Site 2 (Suncheon Bay wetland) is a brackish water zone where the sea and river meet and offers a good view of a natural landscape with various types of 
birds, especially in the section of the zone where the river narrows. As a shipping route is formed along the midstream and upstream of the river at Site 3 (Goesan Lake and Sanmagi-yetgil), it is easy to recognize the landscapes surrounding the ship (see Table 3).

Table 3. Landscape viewed from the ship.

\begin{tabular}{|c|c|c|c|}
\hline & Nakdong River Estuary & Suncheon Bay Wetland & $\begin{array}{l}\text { Goesan Lake and } \\
\text { Sanmagi-Yetgil }\end{array}$ \\
\hline \multicolumn{4}{|l|}{ Far away } \\
\hline & $\begin{array}{l}\text { Riverside park and } \\
\text { apartments }\end{array}$ & $\begin{array}{l}\text { Tidal flats and reed } \\
\text { communities }\end{array}$ & $\begin{array}{l}\text { Sanmagi village and } \\
\text { riverside }\end{array}$ \\
\hline \multicolumn{4}{|l|}{ Medium distance } \\
\hline & $\begin{array}{c}\text { Hwamyeong marina and } \\
\text { ecological park }\end{array}$ & $\begin{array}{c}\text { Yongsan observatory and } \\
\text { river ecology }\end{array}$ & $\begin{array}{l}\text { Alluvial sand and river } \\
\text { ecology }\end{array}$ \\
\hline \multicolumn{4}{|l|}{ Close distance } \\
\hline & Ilung-do ecological park & $\begin{array}{l}\text { Reed communities and } \\
\text { bird watchers }\end{array}$ & $\begin{array}{l}\text { Rare rocks and pine } \\
\text { forests }\end{array}$ \\
\hline
\end{tabular}

\subsection{Demographic Characteristics}

The demographic characteristics of the survey respondents are presented in Table 4. Among the respondents, only one resided in the target site of the Suncheon Bay wetland, while all others resided in areas outside the target site. Of the 30 respondents, 21 were men $(70.0 \%)$ and 9 were women $(30.0 \%)$. The respondents were mainly undergraduate students with experience in theoretical learning.

Table 4. Demographic characteristics of respondents.

\begin{tabular}{|c|c|c|c|c|c|c|c|}
\hline \multicolumn{2}{|c|}{ Classification } & \multirow{2}{*}{$\begin{array}{c}\text { Frequency } \\
21\end{array}$} & \multirow{2}{*}{$\begin{array}{c}\text { Ratio (\%) } \\
70.0\end{array}$} & \multicolumn{2}{|c|}{ Classification } & \multirow{2}{*}{$\begin{array}{c}\text { Frequency } \\
30\end{array}$} & \multirow{2}{*}{$\begin{array}{c}\text { Ratio (\%) } \\
100\end{array}$} \\
\hline Gender & Male & & & Location of & Field & & \\
\hline & Female & 9 & 30.0 & & Not field & - & - \\
\hline \multirow{4}{*}{ Age } & $20 \mathrm{~s}$ & 24 & 80.0 & \multirow{2}{*}{ Residence } & Local & 1 & 3.3 \\
\hline & $30 \mathrm{~s}$ & 3 & 10.0 & & Not local & 29 & 96.7 \\
\hline & $40 \mathrm{~s}$ & 3 & 10.0 & \multirow[t]{2}{*}{ Job } & $\begin{array}{l}\text { Senior at } \\
\text { university }\end{array}$ & 24 & 80.0 \\
\hline & $50 \mathrm{~s}$ & - & - & & $\begin{array}{l}\text { General and } \\
\text { Professional }\end{array}$ & 6 & 20.0 \\
\hline
\end{tabular}

\subsection{Target Site-Specific Analysis}

To analyze satisfaction with the use of eco-tour ships at ecotourism sites, the survey consisted of six questionnaire items: eco-tour ship image, facilities on the eco-tour ship, landscape observed from the eco-tour ship, eco-tour ship course, eco-tour ship operations, and impact of eco-tour ships on ecotourism. The findings for each target site are presented in Table 5. 
Table 5. Demographic characteristics of the respondents.

\begin{tabular}{|c|c|c|c|c|c|c|c|c|c|c|c|c|c|c|c|c|c|c|}
\hline & \multicolumn{3}{|c|}{ Image } & \multicolumn{3}{|c|}{ Facility } & \multicolumn{3}{|c|}{ Landscape } & \multicolumn{3}{|c|}{ Course } & \multicolumn{3}{|c|}{ Operation } & \multicolumn{3}{|c|}{ Influence } \\
\hline & $\mathbf{M}$ & $\mathbf{N}$ & SD & $\mathbf{M}$ & $\mathbf{N}$ & SD & $\mathbf{M}$ & $\mathbf{N}$ & SD & $\mathbf{M}$ & $\mathbf{N}$ & SD & $\mathbf{M}$ & $\mathbf{N}$ & SD & $\mathbf{M}$ & $\mathbf{N}$ & SD \\
\hline Group 1 & 5.27 & 30 & 1.202 & 7.27 & 30 & 0.98 & 4.67 & 30 & 0.758 & 5.00 & 30 & 0.947 & 6.37 & 30 & 0.850 & 4.47 & 30 & 0.860 \\
\hline Group 2 & 7.40 & 30 & 0.968 & 6.57 & 30 & 1.478 & 7.20 & 30 & 1.472 & 6.57 & 30 & 1.251 & 7.10 & 30 & 1.269 & 7.00 & 30 & 1.509 \\
\hline Group 3 & 4.63 & 30 & 1.189 & 4.83 & 30 & 1.464 & 8.40 & 30 & 0.770 & 7.37 & 30 & 1.129 & 7.23 & 30 & 1.104 & 7.93 & 30 & 1.015 \\
\hline
\end{tabular}

Note: Group 1: Nakdong River estuary; Group 2: Suncheon Bay wetland; Group 3: Goesan Lake and Sanmagi-yetgil.

\subsubsection{Nakdong River Estuary}

The mean score of eco-tour ship image for the Nakdong River estuary was found to be 5.27. The site scored the highest mean score of 7.27 for facilities on the eco-tour ship, while the lowest score was obtained for landscapes observed from the eco-tour ship as well as the suitability of the tour course. The operations and impact of eco-tour ships on ecotourism also received lower scores.

\subsubsection{Suncheon Bay Wetland}

The mean score of eco-tour ship image for Suncheon Bay wetland was 7.40, the highest of all the items. A relatively stable evaluation of 6.57 was obtained for facilities on the eco-tour ship and the suitability of the tour course. Landscape observed from the eco-tour ship, operations, and the impact of eco-tour ships on ecotourism scored 7.20,7.10, and 7.00, respectively.

\subsubsection{Goesan Lake and Sanmagi-Yetgil}

The mean score of the eco-tour ship image for Goesan Lake and Sanmagi-yetgil was 4.63, the lowest of all the items. Facilities on the eco-tour ship (4.83) also scored low, while landscape observed from the eco-tour ship was evaluated the highest at 8.40 . Suitability of the tour course and operations also received high scores of 7.37 and 7.23, respectively. Among all three target sites, the impact of eco-tour ships on ecotourism received the highest score of 7.93 for Goesan Lake and Sanmagi-yetgil.

The eco-tour ship at Goesan Lake and Sanmagi-yetgil was thus found to have received the highest evaluation in four areas of investigation, except eco-tour ship image and facilities on the eco-tour ship. The landscape observed from the eco-tour ship, in particular, was found to have elicited the highest scores from the survey respondents.

\subsection{Demographic Characteristics}

The survey results were examined using the Kruskal-Wallis test as a nonparametric test, with $1 \%$ significance probability $(p=0.01)$. For each test item, the Mann-Whitney test was used to confirm the significance of the compared results of the three target sites.

\subsubsection{Satisfaction with Eco-Tour Ship Image and Facilities}

The satisfaction analysis regarding eco-tour ship image showed that the Nakdong River estuary, Suncheon Bay wetland, and Sanmagi-yetgil had mean scores of 5.27, 7.40, and 4.63, respectively. The Kruskal-Wallis nonparametric test found significant differences among the three groups. The Mann-Whitney test showed that the satisfaction level differed significantly $(p<0.01)$ for each group.

The satisfaction analysis regarding facilities on the eco-tour ship found that the Nakdong River estuary, Suncheon Bay wetland, and Sanmagi-yetgil had mean scores of 7.27, 6.57, and 4.83, respectively. The Kruskal-Wallis nonparametric test found significant differences among the three groups. The Mann-Whitney test showed that the difference in satisfaction between Groups 1 and 3 and Groups 2 and 3 was significant $(p<0.01)$, while that between Groups 1 and 2 was not significant $(p>0.01)$ (Table 6). 
Table 6. Result of satisfaction analysis regarding image and facilities.

\begin{tabular}{|c|c|c|c|c|c|c|c|c|c|}
\hline & \multicolumn{5}{|c|}{ Kruskal-Wallis } & \multicolumn{4}{|c|}{ Mann-Whitney } \\
\hline & & $\mathbf{N}$ & $\mathrm{AR}^{1}$ & Chi-Square & $p$-Value & & $\begin{array}{l}\text { Group } \\
1 \text { vs. } 2 \\
\end{array}$ & $\begin{array}{l}\text { Group } \\
1 \text { vs. } 3 \\
\end{array}$ & $\begin{array}{l}\text { Group } \\
2 \text { vs. } 3 \\
\end{array}$ \\
\hline \multirow{3}{*}{ Image } & Group 1 & 30 & 37.87 & \multirow{3}{*}{47.725} & \multirow{3}{*}{0.000} & Mann-Whitney U & 82.500 & 311.500 & 44.500 \\
\hline & Group 2 & 30 & 71.27 & & & Wilcoxon W & 547.500 & 776.500 & 509.500 \\
\hline & Group 3 & 30 & 27.37 & & & $p$-value & 0.000 & 0.034 & 0.000 \\
\hline \multirow{3}{*}{ Facility } & Group 1 & 30 & 61.97 & \multirow{3}{*}{33.897} & \multirow{3}{*}{0.000} & Mann-Whitney U & 326.000 & 80.000 & 182.000 \\
\hline & Group 2 & 30 & 50.30 & & & Wilcoxon W & 791.000 & 545.000 & 647.000 \\
\hline & Group 3 & 30 & 24.23 & & & $p$-value & 0.058 & 0.000 & 0.000 \\
\hline
\end{tabular}

\subsubsection{Satisfaction with Landscape and Course}

The satisfaction analysis regarding the landscape observed from the eco-tour ship showed that the Nakdong River estuary, Suncheon Bay wetland, and Sanmagi-yetgil had mean scores of 4.67, 7.20, and 8.40, respectively. The Kruskal-Wallis nonparametric test found significant differences among the three groups. The Mann-Whitney test showed that the satisfaction level differed significantly $(p<0.01)$ for each group.

The satisfaction analysis regarding the eco-tour ship course showed that the Nakdong River estuary, Suncheon Bay wetland, and Sanmagi-yetgil had mean scores of 5.00, 6.57, and 7.37, respectively. The Kruskal-Wallis nonparametric test found significant differences among the three groups. The Mann-Whitney test showed that the satisfaction level differed significantly $(p<0.01)$ for each group (Table 7).

Table 7. Results of satisfaction analysis regarding landscape and course.

\begin{tabular}{|c|c|c|c|c|c|c|c|c|c|}
\hline & \multicolumn{5}{|c|}{ Kruskal-Wallis } & \multicolumn{4}{|c|}{ Mann-Whitney } \\
\hline & & $\mathbf{N}$ & AR & Chi-Square & $p$-Value & & $\begin{array}{l}\text { Group } \\
1 \text { vs. } 2\end{array}$ & $\begin{array}{l}\text { Group } \\
1 \text { vs. } 3\end{array}$ & $\begin{array}{l}\text { Group } \\
2 \text { vs. } 3\end{array}$ \\
\hline \multirow{3}{*}{ Landscape } & Group 1 & 30 & 17.72 & \multirow{3}{*}{59.325} & \multirow{3}{*}{0.000} & Mann-Whitney U & 64.500 & 2.000 & 227.000 \\
\hline & Group 2 & 30 & 50.92 & & & Wilcoxon W & 529.500 & 467.000 & 692.000 \\
\hline & Group 3 & 30 & 67.87 & & & $p$-value & 0.000 & 0.000 & 0.001 \\
\hline \multirow{3}{*}{ Course } & Group 1 & 30 & 22.08 & \multirow{3}{*}{42.370} & \multirow{3}{*}{0.000} & Mann-Whitney U & 150.500 & 47.000 & 44.500 \\
\hline & Group 2 & 30 & 50.12 & & & Wilcoxon W & 615.500 & 512.000 & 509.500 \\
\hline & Group 3 & 30 & 64.30 & & & $p$-value & 0.000 & 0.000 & 0.000 \\
\hline
\end{tabular}

\subsubsection{Eco-Tour Ship Operations and the Impact on Ecotourism}

The satisfaction analysis regarding eco-tour ship operations showed that the Nakdong River estuary, Suncheon Bay wetland, and Sanmagi-yetgil had mean scores of 6.37, 7.10, and 7.23, respectively. The Kruskal-Wallis nonparametric test found significant differences among the three groups. The Mann-Whitney test showed that the difference in satisfaction between Groups 1 and 2 and Groups 1 and 3 was significant $(p<0.01)$, while that between Groups 2 and 3 was not significant $(p>0.01)$.

The satisfaction analysis regarding the impact of eco-tour ships on ecotourism showed that the Nakdong River estuary, Suncheon Bay wetland, and Sanmagi-yetgil had mean scores of 4.47, 7.00, and 7.93, respectively. The Kruskal-Wallis nonparametric test found significant differences among the three groups. The Mann-Whitney test showed that the difference in satisfaction between Groups 1 and 2 and Groups 1 and 3 was significant $(p<0.01)$, while that between Groups 2 and 3 was not significant $(p>0.01)$ (Table 8$)$. 
Table 8. Result of satisfaction analysis regarding operations and impact.

\begin{tabular}{|c|c|c|c|c|c|c|c|c|c|}
\hline & \multicolumn{5}{|c|}{ Kruskal-Wallis } & \multicolumn{4}{|c|}{ Mann-Whitney } \\
\hline & & $\mathbf{N}$ & AR & Chi-Square & $p$-Value & & $\begin{array}{l}\text { Group } \\
1 \text { vs. } 2\end{array}$ & $\begin{array}{l}\text { Group } \\
1 \text { vs. } 3\end{array}$ & $\begin{array}{l}\text { Group } \\
2 \text { vs. } 3\end{array}$ \\
\hline \multirow{3}{*}{ Operation } & Group 1 & 30 & 32.58 & \multirow{3}{*}{12.142} & \multirow{3}{*}{0.002} & Mann-Whitney U & 278.500 & 234.000 & 419.000 \\
\hline & Group 2 & 30 & 50.18 & & & Wilcoxon W & 743.500 & 699.000 & 884.000 \\
\hline & Group 3 & 30 & 53.73 & & & $p$-value & 0.008 & 0.001 & 0.634 \\
\hline \multirow{3}{*}{ Influence } & Group 1 & 30 & 18.05 & \multirow{3}{*}{54.881} & \multirow{3}{*}{0.000} & Mann-Whitney U & 75.500 & 1.000 & 294.000 \\
\hline & Group 2 & 30 & 52.78 & & & Wilcoxon W & 540.500 & 466.000 & 759.000 \\
\hline & Group 3 & 30 & 65.67 & & & $p$-value & 0.000 & 0.000 & 0.018 \\
\hline
\end{tabular}

\section{Discussion}

This study comparatively analyzed the satisfaction with some eco-tour ships used in ecotourism. The levels of ecotourist satisfaction with the three target sites were comparatively analyzed, and the findings are based on relative values.

Visitors' satisfaction with their experiences in a specific place influences their decisions for future travel and their motivation [24-27]. Thus, the factors that influence visitor motivation may be discussed based on the satisfaction analysis of eco-tour ships.

The natural resources and landscapes that can be observed from the eco-tour ship appear to have the strongest influence on ecotourism motivation. Compared to the Nakdong River estuary, the Sanmagi-yetgil presents a landscape of high natural resource value, from the strange rock formations to dense pine tree vegetation in the surrounding waterside landscape. The Nakdong River estuary scored low on landscape evaluation despite having good eco-tour ship image and facilities, which was a factor reducing ecotourists' motivation. The landscape at the Nakdong River estuary overlaps with the urban areas in the vicinity, and the river is too open and wide to be favored. This finding is in line with a previous study on sustainable tourism and target site management [14], where ecotourists' motivation was influenced to a great degree by positive factors, including the surrounding greenery and conserved forests, rather than negative factors, such as noise and illegal buildings. The natural and cultural diversity of the landscape and the tour course recognized by ecotourists are likely to be interconnected [18,21-23].

Eco-tour ship operations, such as commentary, reservation system, and the connection between facilities in the vicinity, are likely to influence ecotourists' motivation. The influence seems to result from the combined effect of satisfaction with operations and operation time as well as the landscape and tour course. The eco-tour ships at Suncheon Bay wetland and Sanmagi-yetgil, compared to the Nakdong River estuary, were found to have a greater impact on ecotourism. This finding coincided with previous studies reporting the impact of the commentary system on ecotourism satisfaction [34], where the quality of the commentary seemed to have determined the success of the ecotourism program. The development of a program that suits the diverse needs of ecotourists could have an influence on their travel motivation [35].

Based on the findings of satisfaction analysis regarding eco-tour ship image, ecotourist motivation seems to be influenced by visual images, such as the use of timber to build ships, which promotes the positive balance between the natural environment and coastal ecosystem.

In addition, we can discuss ways to promote ecotourism by presenting problems that arise in the use of eco-tour ships in Korea.

Ecotourism with eco-tour ships enables the exploration and experience of water ecosystems using a vessel. Therefore, the exterior and the convenience facilities of the ship may play an important role in promoting ecotourism. The current ships used for ecotourism in Korea were made for exploration purposes or were repurposed from ships that were originally used for other purposes; they are at 
the beginner level. The image of the ships should be made eco-friendly, and the convenience of the facilities on the ships needs to be enhanced to create ships dedicated to ecotourism.

For ecotourists, the landscape in the ecosystem has great significance. In this regard, artificial landscape elements should be reduced, and beautiful landscape planning should be reinforced to help revitalize ecotourism.

For the course and operation of eco-tour ships, it is necessary to develop courses and diversify programs designed for exploration and monitoring to provide environmental education and raise environmental awareness among tourists. It was found to be more meaningful to allow tourists to choose a course rather than providing them with long courses, so we need to provide tourists with various courses so that they can choose from among them. The establishment of regular navigation and commentary systems to make ship courses sustainable can also contribute to the promotion of ecotourism.

Ecotourism aims to preserve the natural ecosystem and properly change the landscape. This will help preserve the environment and play a positive role in addressing climate change.

\section{Conclusions}

In ecotourism, consideration of the role of eco-tour ships in providing opportunities to explore the natural ecosystem and experience natural resources is paramount.

This study targeted ecotourists with experience on eco-tour ships at three ecotourism sites in Korea: the Nakdong River estuary, Suncheon Bay wetland, and Sanmagi-yetgil. Tourist satisfaction was analyzed with respect to six factors: eco-tour ship image, facilities on the eco-tour ship, the landscape observed from the eco-tour ship, eco-tour ship course, eco-tour ship operations, such as ecotourism commentary, and impact of the eco-tour ships on ecotourism. The findings led to the following three conclusions:

1. The satisfaction analysis for eco-tour ship image revealed no significant difference between the Nakdong River estuary and Sanmagi-yetgil $(p>0.01)$, while the Suncheon Bay wetland showed a significant difference $(p<0.01)$. This is because the eco-tour ship at Suncheon Bay wetland was manufactured for exploring the ecosystem rather than as a means of water transport. In addition, it is assumed that the fact that the ship was built using timber, which better suits the natural environment and coastal ecosystem, had a positive impact on the visual image. The satisfaction with the facilities on eco-tour ships was found not to differ significantly between the Nakdong River estuary and Suncheon Bay wetland, while Sanmagi-yetgil showed a significant difference. This is due to the relatively poor condition of the ship at Sanmagi-yetgil, compared to the Nakdong River estuary and Suncheon Bay wetland, and the external appearance of the ship presented the image of a water transport ship or cruise ship more than an eco-tour ship.

2. The satisfaction analysis regarding the landscape observed from the eco-tour ship showed significant differences in the mean values for the three target sites: Sanmagi-yetgil (8.40), Suncheon Bay wetland (7.20), and Nakdong River estuary (4.67). These values are based on the qualitative evaluation of the landscape as seen from the eco-tour ship. It is presumed to have been influenced by the nature and diversity of the landscape and the width of the river. The satisfaction with the tour course was found to differ significantly, as shown by the mean values: Sanmagi-yetgil (7.37), Suncheon Bay wetland (6.57), and Nakdong River estuary (5.00). There appears to be a correlation between the landscape and the tour course as evaluated by the respondents. Notably, Sanmagi-yetgil offered a comparatively broader choice of tour course time and a high diversity of available programs for ecotourists than the Nakdong River and Suncheon Bay wetland, which is thought to have led to the higher score.

3. The satisfaction analysis regarding eco-tour ship operations showed no significant difference between Suncheon Bay wetland and Sanmagi-yetgil $(p=0.634)$, while the Nakdong River estuary showed a significant difference. The relatively low satisfaction with the eco-tour ship operation at the Nakdong River estuary is due to the low scores for eco-tour ship commentary, reservation system, and linking with the facilities in the vicinity, while it is presumed that the operation time 
as well as the landscape observed from the eco-tour ship and the tour course had a combined influence on satisfaction.

Furthermore, the satisfaction analysis regarding the impact of the eco-tour ships on ecotourism showed no significant difference between Suncheon Bay wetland and Sanmagi-yetgil $(p=0.018)$, while the Nakdong River estuary showed a significant difference. The impact on ecotourism was higher in the Suncheon Bay wetland and Sanmagi-yetgil than in the Nakdong River estuary.

This study comparatively analyzed the level of satisfaction self-reported by ecotourists regarding the experience of eco-tour ships at three different sites. Eco-tour ships are used as instruments in ecotourism programs, and enhanced satisfaction improves the probability of return visits $[45,46]$. Thus, there is a need to incorporate the characteristics of ecological resources with the well-thought operation and increased functional suitability of eco-tour ships to improve ecotourism satisfaction.

Ecotourism ultimately aims to preserve the ecosystem and to support environmental conservation in natural areas. In addition, the eco-tour ships operating in the three places studied in this paper have elements useful for promoting ecotourism and can enhance its potential. Our findings showed the satisfaction level of the users with the theme of ecotourism.

Further studies should continue to investigate a diverse range of infrastructures and programs, such as eco-tour ships, with the potential to enhance ecotourism values.

Author Contributions: B.-C.A. designed the research and analyzed the data; E.-Y.P. designed the research and collected the field data. All authors have read and agreed to the published version of the manuscript.

Funding: This study was supported by the 2019 research fund from Wonkwang University.

Conflicts of Interest: The authors declare no conflict of interest. The sponsors had no role in the design of the study; the collection, analyses, or interpretation of data; the writing of the manuscript; or the decision to publish the results.

\section{References}

1. Fennell, D.A. Ecotourism: An Introduction; Routledge: New York, NY, USA, 1999.

2. Lima, A.C.; Assis, J.; Sayanda, D.; Sabino, J.; Oliveira, R.F. Impact of ecotourism on the fish fauna of Bonito region (Mato Grosso do Sul State, Brazil): Ecological, behavioural and physiological measures. Neotrop. Ichthyol. 2014, 12, 133-143. [CrossRef]

3. Kang, M.H. Ecotourists' Travel Motivations and Attitudes in Korea: Scales Development and Comparative Analysis on Tourists Groups. Ph.D. Thesis, Seoul National University, Seoul, Korea, 1999.

4. Johnson, A.F.; Gonzales, C.; Townsel, A.; Cisneros-Montemayor, A.M. Marine ecotourism in the Gulf of California and the Baja California Peninsula: Research trends and information gaps. Sci. Mar. 2019, 83, 177-185. [CrossRef]

5. Christopher, A.K.; Renzo, G.; Brett, D.; Kerry, T.; Luz, M.V.; Agusto, D.; Juan, C.L.; Douglas, W.Y. The market triumph of ecotourism: An economic investigation of the private and social benefits of competing land uses in the Peruvian Amazon. PLoS ONE 2010, 5, e13015.

6. Buckley, R.C. Ecotourism accreditation in Australia. In Tourism Ecolabelling: Certification and Promotion of Sustainable Management; Font, X., Buckley, R.C., Eds.; CABI: Wallingford, UK, 2001; pp. 165-174.

7. Cole, D.N. Minimizing conflict between recreation and nature conservation. In Ecology of Greenways: Design and Function of Linear Conservation Areas; Smith, D.S., Hellmund, P.C., Eds.; University of Minnesota Press: Minneapolis, MN, USA, 1993; pp. 105-122.

8. Amalu, T.E.; Otop, O.O.; Duluora, E.I.; Omeje, V.U.; Emeana, S.K. Socio-economic impacts of ecotourism attractions in Enugu state, Nigeria. GeoJournal 2017, 83, 1257-1269. [CrossRef]

9. Kim, S.T.; Yoo, K.M.; Kim, N.J. Analysis of economic impacts of ecotourism experience programs at national parks. J. Tour. Stud. 2012, 24, 97-117.

10. Park, E.B.; Kim, H.; Choi, H.S. The study on the effect of eco-tourist's attitude, behavior and satisfaction on tour expenses at Suncheon Bay. J. Korean Inst. Landsc. Archit. 2014, 42, 50-63. [CrossRef]

11. Kang, M.S.; Kim, Y.S. A study on the influence of ecotourist's environmental attitudes and customer satisfaction-Focusing on moderating effects of ecotourism attractiveness. J. Korea Commer. Educ. 2017, 31, $23-43$. 
12. Kim, J.; Ko, D.H. A change in tourism environmental attitudes through ecotourism activities-Focusing on ecotourism participants in Upo Wetlands. J. Korea Inst. Landsc. Archit. 2011, 39, 56-64. [CrossRef]

13. An, B.C. Ecotourism+26; Educatory: Seoul, Korea, 2019.

14. Prokopiou, D.; Nikolaidou, E.; Mavridoglou, G.; Manologlou, S.; Tselentis, B. Sustainable tourism and destination management: The Greek Island of Poros. WIT Trans. Ecol. Environ. 2017, 226, 505-515.

15. Gamez, M.A.F.; Serrano, J.A.S.; Gil, A.C.; Ruiz, A.J.C. Cruise passengers' intention and sustainable management of cruise destinations. Sustainability 2019, 11, 1929. [CrossRef]

16. Manley, B.; Elliot, S.; Jacobs, S. Expedition cruising in the Canadian Arctic: Visitor motives and the influence of education programming on knowledge, attitudes, and behaviours. Resources 2017, 6, 23. [CrossRef]

17. Wiberg, D.S. Development of a Survey Measuring Visitor Satisfaction and Service Quality of Cultural and Natural Sites in Belize. Ph.D. Thesis, Utah State University, Logan, UT, USA, 2009.

18. Chavez, J. Ecotourism TAP: Metodología para un ec\#oturismo ambie\#ntalmente plani\#ficado; Trillas: Mexico City, Mexico, 2005.

19. Fonseca, F.G. Challenges and opportunities in the world of tourism from the point of view of ecotourism. High. Learn. Res. Commun. 2012, 2, 5-22. [CrossRef]

20. Araujo, L.M.D. Stakeholder Participation in Regional Tourism Planning: Brazil's Costa Dourada Project; Sheffield Hallam University: Sheffield, UK, 2000; p. 375.

21. Wood, M.E. Ecotourism: Principles, Practices \& Policies for Sustainability; United Nations Publication: New York, USA, 2002; p. 32.

22. Ross, S.; Wall, G. Ecotourism: Towards congruence between theory and practice. Tour. Manag. 1999, 20, 123-132. [CrossRef]

23. Kenawy, E.H.; Shaw, D. Developing a More Effective Regional Planning Framework in Egypt: The Case of Ecotourism. In WIT Transactions on Ecology and the Environment; WIT Press: Southampton, UK, 2014; p. 187.

24. Choo, S.W. The framework of decision making for choice of camping site selection attributes according to camping motivation. J. Digit. Converg. 2015, 13, 225-234. [CrossRef]

25. Kim, T.D.; Koo, J.H.; Lee, S.J.; Choi, A.R. Selection attributes importance and satisfaction for research on the development of the Baekdudaegan. J. Digit. Converg. 2016, 14, 19-30. [CrossRef]

26. Kim, H.; Chang, H.S.; Hwang, J.S. A study of tourism motivation and destination choice attributes in tourism behavior: Focusing on Ansan city. Int. J. Tour. Hosp. Res. 2014, 28, 219-232.

27. You, H.S.; Nah, Y.J. The effect of motivation and expectation-perceived experience conformation on ecotourist satisfaction. J. Tour. Inst. Northeast Asia 2019, 15, 187-208.

28. Garcia, H.C.; Saura, I.G.; Garcia, R.R.; Calarza, M.G. The "Sun and Beach" tourism destination image: An application to the case of Cuba from the Spanish tourist-origin market. Tour. Rev. 2004, 59, 16-24. [CrossRef]

29. Enright, M.; Newton, J. Tourism destination competiveness: A quantitative approach. Tour. Manag. 2004, 25, 77-78. [CrossRef]

30. Oh, S.H.; Ko, G.S. Importance-performance analysis of attractiveness assessment for Island tourism destination: A case of Jeju Island. J. Tour. Res. 2005, 19, 45-58.

31. Yang, S.P.; Kwak, Y.D. The effects of attractiveness, attitude, and perceived value on eco-tourists satisfaction. J. Tour. Res. 2010, 25, 271-290.

32. Cracolici, M.F.; Nijkamp, P. The attractiveness and competiveness of tourist destination: A study of southern Italian region. Tour. Manag. 2008, 30, 34-36.

33. Formica, S.; Uysal, M. Destination attractiveness based on supply and demand evaluations: An analytic framework. J. Travel Res. 2006, 4, 418-430. [CrossRef]

34. Chun, J.H.; Lim, Y.W. Relationship between tourism interpretation quality and tourist satisfaction in ecotourism. J. Korea Acad. Ind. Coop. Soc. 2016, 17, 520-527.

35. Kang, M.S.; Kim, Y.S. Adjustment effect of public involvement between perceived value and customer satisfaction of Ecological Tourism. Acad. Soc. Glob. Bus. Adm. 2017, 13, 187-205. [CrossRef]

36. An, B.C. An importance and satisfaction analysis for improvement efficiency use of waterfront: A focus on the waterfront analysis for domestic and foreign dragon boat festival. J. Korean Inst. Landsc. Archit. 2016, 44, 86-99. [CrossRef]

37. Ministry of Culture, Sports and Tourism. A Standard Model for Greenhouse Gas Inventory in Tourism Industry; Ministry of the Interior and Safety: Sejong, Korea, 2011. 
38. Kuo, N.W.; Chen, P.H. Quantifying energy use, carbon dioxide emission, and other environmental loads from island tourism based on a life cycle assessment approach. J. Clean. Prod. 2009, 17, 1324-1330. [CrossRef]

39. Sharp, H.; Grundius, J.; Heinonen, J. Carbon footprint of inbound tourism to Iceland: A consumption-based life-cycle assessment including direct and indirect emissions. Sustainability 2016, 8, 1147. [CrossRef]

40. Korea Environment Institute. Development and Evaluation of Indicators for Low Carbon Ecotourism; Korea Environment Institute: Sejong, Korea, 2009.

41. Busan Development Institute. Value Evaluation and Management Program in Nakdong Estuary; Busan Development Institute: Busan, Korea, 2005; pp. 1-5.

42. Busan Metropolitan City. Ecological System Monitoring in Nakdong Estuary 2015-2016. Available online: www.busan.go.kr (accessed on 25 July 2019).

43. Seo, E.Y.; Lee, C.S.; Won, J.M. A comparative analysis on the urban regeneration projects of waterfront areas in three major world cities: Focusing on London, Paris, Seoul's Waterfront Projects. J. Korea Plan. Assoc. 2012, 47, 109-122.

44. Busan Development Institute. Sustainable Management Plan of Nakdong Estuary; Busan Development Institute: Busan, Korea, 2007.

45. Jang, M.S.; Kim, K.H. Factors influencing ecotourists' return visits-Focusing on the Upo Wetlands. J. Korean Isl. 2018, 30, 69-87. [CrossRef]

46. Yoon, Y.; Uysal, M. An examination of the effects of motivation and satisfaction on destination loyalty. Tour. Manag. 2005, 26, 45-56. [CrossRef]

Publisher's Note: MDPI stays neutral with regard to jurisdictional claims in published maps and institutional affiliations.

(C) 2020 by the authors. Licensee MDPI, Basel, Switzerland. This article is an open access article distributed under the terms and conditions of the Creative Commons Attribution (CC BY) license (http://creativecommons.org/licenses/by/4.0/). 